\title{
PENGARUH ASKORBIL FOSFAT MAGNESIUM SEBAGAI SUMBER VITAMIN C TERHADAP PEMATANGAN GONAD UDANG WINDU (Penaeus monodon) ASAL TAMBAK
}

\author{
Marzuqi M. ${ }^{*}$, K. Suwirya*) dan Z. I. Azwar ${ }^{*}$
}

\begin{abstract}
ABSTRAK
Percobaan ini dilakukan untuk mendapat gambaran kebutuhan vitamin $\mathrm{C}$ dalam pematangan gonad udang windu betina asal tambak.

Induk udang windu (Penaeus monodon) dengan bobot awal berkisar 98,86-99,27 g diberi pakan semi murni dengan perbedaan kadar askorbil fosfat magnesium $0,00 \% ; 0,05 \% ; 0,10 \%$ dan $0,15 \%$ selama pemeliharaan 58 hari. Hasil percobaan menunjukkan bahwa suplementasi askorbil fosfat magnesium sebagai sumber vitamin $\mathrm{C}$ sebanyak $0,10 \%$ telah dapat menstimulasi pematangan gonad induk udang.
\end{abstract}

\begin{abstract}
The effect of dietary ascorbyl phosphate magnesium as vitamin C source on gonadal maturation of tiger shrimp broodstock (Penaeus monodon) from brackishwater pond. By: Marzuqi M., K. Suwirya and Z.I. Azwar.
\end{abstract}

\begin{abstract}
The experiment was conducted to examine the requirement of vitamin $C$ for gonadal maturation of tiger shrimp (Penaeus monodon) from brackishwater pond.

The female of tiger shrimp (Penaeus monodon), weighing 98.86-99.27 $\mathrm{g}$ were fed with semi purified diets containing different levels of ascorbyl phosphate magnesium: $0.00 \%, 0.05 \%, 0.10 \%$ and $0.15 \%$ for 58-day rearing. The result of feeding experiment indicated that supplementation of ascorbyl phosphate magnesium at $0.10 \%$ could promote gonadal maturation.
\end{abstract}

KEYWORDS: Vitamin C; gonadal maturation; Penaeus monodon; askorbil fosfat magnesium.

\section{PENDAHULUAN}

Perbaikan mutu induk udang asal tambak, Penaeus monodon dapat dilakukan melalui manipulasi lingkungan, genetik, hormonal, dan pakan. Pakan dengan kandungan nutrea yang lengkap dapat mempengaruhi laju perkembangan gonad (Primavera, 1985). Umumnya penelitian kebutuhan nutrisi induk masih sangat terbatas pada kecukupan kebutuhan protein dan lemak, sedangkan penelitian terhadap nutrea lain seperti mineral dan vitamin belum banyak dijangkau. Laven dan Sorgeloos (1991) mengemukakan bahwa, ada dua senyawa yang dianggap penting dalam siklus reproduksi yaitu HUFA dan Vitamin C. Telah dibuktikan bahwa senyawa ini sangat mempengaruhi mutu telur yang dihasilkan. Diduga pula bahwa vitamin $\mathrm{C}$ berpengaruh dalam proses perkembangan gonad. Hal ini didasarkan adanya fluktuasi senyawa ini saat siklus reproduksi pada beberapa spesies ikan dan udang yang ditangkap dari alam seperti pada ikan Carassius carassius (Saeymour, 1981), Oncorhynchus mykiss (Sandnes, 1984), dan udang Palaemon serratus (Guary et al., 1975) Oreochromis sp. (Azwar, 1997)

Vitamin C merupakan senyawa tidak stabil, mudah teroksidasi selama proses pembuatan dan penyimpanan pakan, sehingga kandungannya dalam ransum cepat menurun. Untuk mengurangi pengaruh oksidasi tersebut, saat ini telah diproduksi turunan vitamin $\mathrm{C}$ yang lebih stabil terhadap pengaruh oksidasi seperti askorbil fosfat magnesium (AsPMg), askorbil sulfat ( $\mathrm{AsS}$ ) dan askorbil polifosfat (AsPP).

Bertitik tolak pada permasalahan di atas, dilakukan percobaan yang bertujuan untuk

*) Peneliti pada Loka Penelitian Perikanan Pantai Gondol, Bali 
mengetahui pengaruh suplementasi turunan vitamin $\mathrm{C}$ (askorbil fosfat magnesium) sebagai sumber vitamin $\mathrm{C}$ terhadap pematangan gonad udang windu.

\section{BAHAN DAN METODE}

Dalam percobaan ini digunakan pakan buatan dengan kandungan protein $50,00 \%$ dan lipid $8 \%$ dengan komposisi seperti disajikan pada Tabel 1. Dalam pakan disuplementasikan askorbil fosfat magnesium pada kadar $0,00 \% ; 0,05 \% ; 0,10 \%$ dan $0,15 \%$. Pakan dibuat dalam bentuk pelet, dengan bahan perekat karagenan. Hewan uji yang digunakan adalah induk udang windu asal tambak, dengan kisaran bobot betina 98,86-99,27 g dan jantan 67,71-69,86 g. Wadah percobaan yang digunakan adalah bak beton bervolume $16 \mathrm{~m}^{3}$ yang dilengkapi 4 titik aerasi dengan sistem air mengalir, dan penyinaran diatur 12 jam terang dan 12 jam gelap. Setiap bak ditebar 7 pasang induk udang dengan rasio 1:1. Pakan diberikan pada pagi dan sore hari sebanyak $3-4 \%$ dari bobot biomas. Agar kondisi udang tetap sehat maka dilakukan pergantian air sebanyak $125 \%$ per hari. Penyiponan sisa pakan dan kotoran dilakukan pada pagi hari.

Induk udang windu dipelihara selama 36 hari. Kemudian untuk mengetahui respon dari masingmasing perlakuan, setelah hari ke-36 dilakukan ablasi tangkai mata dan dipelihara hingga 22 hari berikutnya. Untuk memonitor pertumbuhan dan tingkat kematangan gonad setiap individu, maka pada tangkai mata diberi tanda atau nomor. Perkembangan gonad diamati setiap hari dengan penggunaan sinar "flash light". Pada akhir percobaan dilakukan pembedahan gonad untuk menentukan Indeks Gonad Somatik (IGS = bobot gonad/bobot tubuh $\times 100 \%$ ) dan Indeks Hepato Somatik (IHS = bobot hepatopankreas/ bobot tubuh $\times 100 \%)$.

Tabel 1. Komposisi pakan yang digunakan dalam penelitian.

Table 1. Composition of the basal diet used in the experiment.

\begin{tabular}{|c|c|c|c|c|}
\hline \multirow{2}{*}{$\begin{array}{l}\text { Komposisi } \\
\text { Ingredient }\end{array}$} & \multicolumn{4}{|c|}{ Ascorbyl phosphate magnesium } \\
\hline & $0.00 \%$ & $0.05 \%$ & $0.10 \%$ & $0.15 \%$ \\
\hline Kasein (Casein) & 55.00 & 55.00 & 55.00 & 55.00 \\
\hline Arginina- $\mathrm{HCl}$ (Arginine- $\mathrm{HCl}$ ) & 3.00 & 3.00 & 3.00 & 3.00 \\
\hline Sukrosa (Sucrose) & 9.00 & 9.00 & 9.00 & 9.00 \\
\hline$\alpha$-Starch & 3.00 & 3.00 & 3.00 & 3.00 \\
\hline Dekstrina (Dextrine) & 3.00 & 3.00 & 3.00 & 3.00 \\
\hline Soybean lecithin & 3.00 & 3.00 & 3.00 & 3.00 \\
\hline Kolesterol (Cholesterol) & 1.00 & 1.00 & 1.00 & 1.00 \\
\hline Campuran vitamin (Vitamin mix ${ }^{\star}$ ) & 0.92 & 0.92 & 0.92 & 0.92 \\
\hline Campuran mineral (Mineral mix ${ }^{* *}$ ) & 8.00 & 8.00 & 8.00 & 8.00 \\
\hline Minyak hati cumi (Squid liver oil) & 4.00 & 4.00 & 4.00 & 4.00 \\
\hline Vitamin $\mathrm{C}$ & 0.00 & 0.05 & 0.10 & 0.15 \\
\hline Karagenan (Carrageenan) & 8.00 & 8.00 & 8.00 & 8.00 \\
\hline Selulose (Cellulose) & 2.08 & 2.03 & 1.98 & 1.93 \\
\hline Tot a l & 100.00 & 100.00 & 100.00 & 100.00 \\
\hline
\end{tabular}

*) Vitamin composition ( $\mathrm{mg} / 100 \mathrm{~g}$ diet): p-aminobenzoic acid 15.80; Biotin 0.63; Inositol 632.00; Niacin 63.20; Ca-panthotenate 94.80; Pyridoxine-HCl 18.96; Riboflavine 12.64; Thiamine- $\mathrm{HCl}$ 6.32; Folic acid 1.26; Cyanocobalamin 0.13; Menadion 6.34; Cholecalciferol 1.88; Vitamin A palmitat 15.00; $\alpha$-tocopherol 50.00

$\left.{ }^{\star *}\right) \quad$ Mineral composition (g/100 g diet): K2HPO4 1.86; Ca3(PO4)2 2.55; Mg SO47H2O 2.84; $\mathrm{NaH} 2 \mathrm{PO} 4.2 \mathrm{H} 2 \mathrm{O} 0.75$. 
Pengamatan kandungan vitamin $\mathrm{C}$ gonad ditentukan dengan High Performance Liquid Chromatography (HPLC) dengan menggunakan "reverse fase column" (Hypersil ODS $5 \mathrm{C}_{8}$ : $4.00 \times 250 \mathrm{~mm}$ ), detektor UV-VIS, Injektor U6K (Model 510 water) dan recorder (data model water 741). Fase mobil yang digunakan adalah bufer asetat dan 1,5 dietil heksilamin. Kecepatan aliran fase mobil adalah $0.8 \mathrm{~mL} /$ menit. Waktu retensi pemisahan vitamin $\mathrm{C}$ adalah 7.8 menit.

\section{HASIL DAN PEMBAHASAN}

Hasil pengamatan terhadap perkembangan gonad induk betina udang uji memperlihatkan bahwa indeks gonad somatik (IGS) tertinggi diperoleh pada perlakuan dengan suplementasi askorbil fosfat magnesium $0,10 \%$ yaitu $1,28 \%$ dan terendah pada kontrol yaitu $1,00 \%$ (Tabel 2).

Hasil analisis ragam antara perlakuan memperlihatkan bahwa suplementasi askorbil fosfat magnesium sangat nyata $(\mathrm{P}<0,05)$ mempengaruhi perkembangan gonad (IGS). IGS induk udang pada suplementasi askorbil fosfat magnesium $0,10 \%$ dan $0,15 \%$ sangat nyata $(\mathrm{P}<0,05)$ lebih tinggi daripada kontrol dan suplementasi $0,05 \%$. Sedangkan IGS antara kontrol dan suplementasi $0,05 \%$ serta antara suplementasi $0,10 \%$ dan $0,15 \%$ tidak memperlihatkan perbedaan yang nyata $(\mathrm{P}>0,05)$. Hasil percobaan ini mendekati hasil yang ditemui oleh Alava et al. (1993) terhadap udang Penaeus japonicus. Induk udang betina yang diberi pakan dengan suplementasi vitamin $\mathrm{A}, \mathrm{E}$ dan $\mathrm{C}$ bentuk askorbil fosfat magnesium masing-masing dosis $15,100,100 \mathrm{mg} / 100 \mathrm{~g}$ pakan mencapai IGS 3,8\% pada akhir penelitian, namun pada perlakuan tanpa disuplementasi vitamin C IGS mencapai hanya 2,0\%. Hasil percobaan Ishibashi et al. (1994) terhadap ikan "Japanese parrot" (Oplegnathus fasciatus) memperlihatkan bahwa ada peningkatan IGS dengan peningkatan suplementasi vitamin $\mathrm{C}$ dalam ransum. Ikan yang menerima pakan dengan suplementasi vitamin $\mathrm{C}$ kadar 0 , $300,1000,3000 \mathrm{mg} / \mathrm{kg}$ pakan memperlihatkan nilai IGS masing-masing 0,$5 ; 0,9 ; 1,4 ; 2,2 \%$ untuk induk betina. Pengamatannya secara mikroskopis pada ovarium menunjukkan bahwa tidak ditemui oosit pada stadium "vitelogenesis" pada indukinduk yang diberi pakan kontrol dan disimpulkannya bahwa suplementasi vitamin $\mathrm{C}$ berperanan dalam proses "vitelogenesis" sel telur.
Kesimpulan ini didukung pula dari hasil percobaan Waagbo et al. (1989) terhadap ikan Oncorhynchus mykiss yang mendapatkan bahwa kandungan "vitelogenin" serum pada induk kontrol lebih rendah dibandingkan pada suplementasi vitamin C $2000 \mathrm{mg} / \mathrm{kg}$ pakan. Dengan demikian kecukupan vitamin $\mathrm{C}$ saat siklus reproduksi sangat berperanan dalam perkembangan sel telur. Sandnes (1984) mengemukakan bahwa saat siklus reproduksi hati akan mensintesis protein tertentu hasil stimulasi hormon estrogen. Djojosoebagio (1991) mengemukakan bahwa dalam biosintesis steroid hormon terjadi beberapa tahap reaksi hidroksilasi dan gangguan terhadap reaksi ini akan menghambat biosintesis hormon. Horning et al. (1984) mengemukakan bahwa vitamin $\mathrm{C}$ dalam ovarium berperanan dalam reaksi hidroksilasi biosintesis steroid hormon reproduksi. Pendapat ini didukung pula dari hasil pengamatan Halver et al. dalam Waagbo et al. (1989) yang mencatat bahwa akumulasi vitamin $\mathrm{C}$ terjadi pada jaringan kolagen yang mengitari telur, dan pada jaringan tersebut terdapat sel teka yang berperanan dalam biosintesis steroid hormon. Percobaan Waagbo et al. (1989) pada ikan trout memperlihatkan bahwa kadar estrogen serum induk yang menerima pakan dengan suplementasi vitamin C 2000 $\mathrm{mg} / \mathrm{kg}$ pakan lebih tinggi dibandingkan perlakuan kontrol, dan kandungan vitamin $\mathrm{C}$ ovarium berkisar $11-39 \mu \mathrm{g} / \mathrm{g}$ pada kontrol, sedangkan pada suplementasi vitamin C $2000 \mathrm{mg} / \mathrm{kg}$ pakan berkisar $464-511 \mu \mathrm{g} / \mathrm{g}$ pada musim reproduksi. Dalam percobaan ini terlihat nyata kandungan vitamin C gonad pada kontrol adalah paling rendah yaitu mencapai $126,87 \mu \mathrm{g} / \mathrm{g}$, sedangkan yang menerima suplementasi askorbil fosfat magnesium berkisar 160,52 hingga 167,25 $\mu \mathrm{g} / \mathrm{g}$ (Tabel 2). Percobaan Azwar (1997) mencatat bahwa ada akumulasi kolesterol pada ovarium ikan nila yang tidak menerima suplementasi askorbil fosfat magnesium, yang menunjukkan bahwa ada gangguan konversi kolesterol ke bentuk steroid hormon reproduksi, karena kolesterol adalah bahan dasar pembentukan steroid hormon.

Rasio bobot hati terhadap tubuh (Indeks Hepato somatik - IHS) akan menunjukkan perubahan selama siklus reproduksi. Indeks tertinggi terjadi pada masa sebelum memijah, dan paling rendah setelah memijah, serta ada korelasi antara nilai IGS dengan IHS (Delahunty dan De 


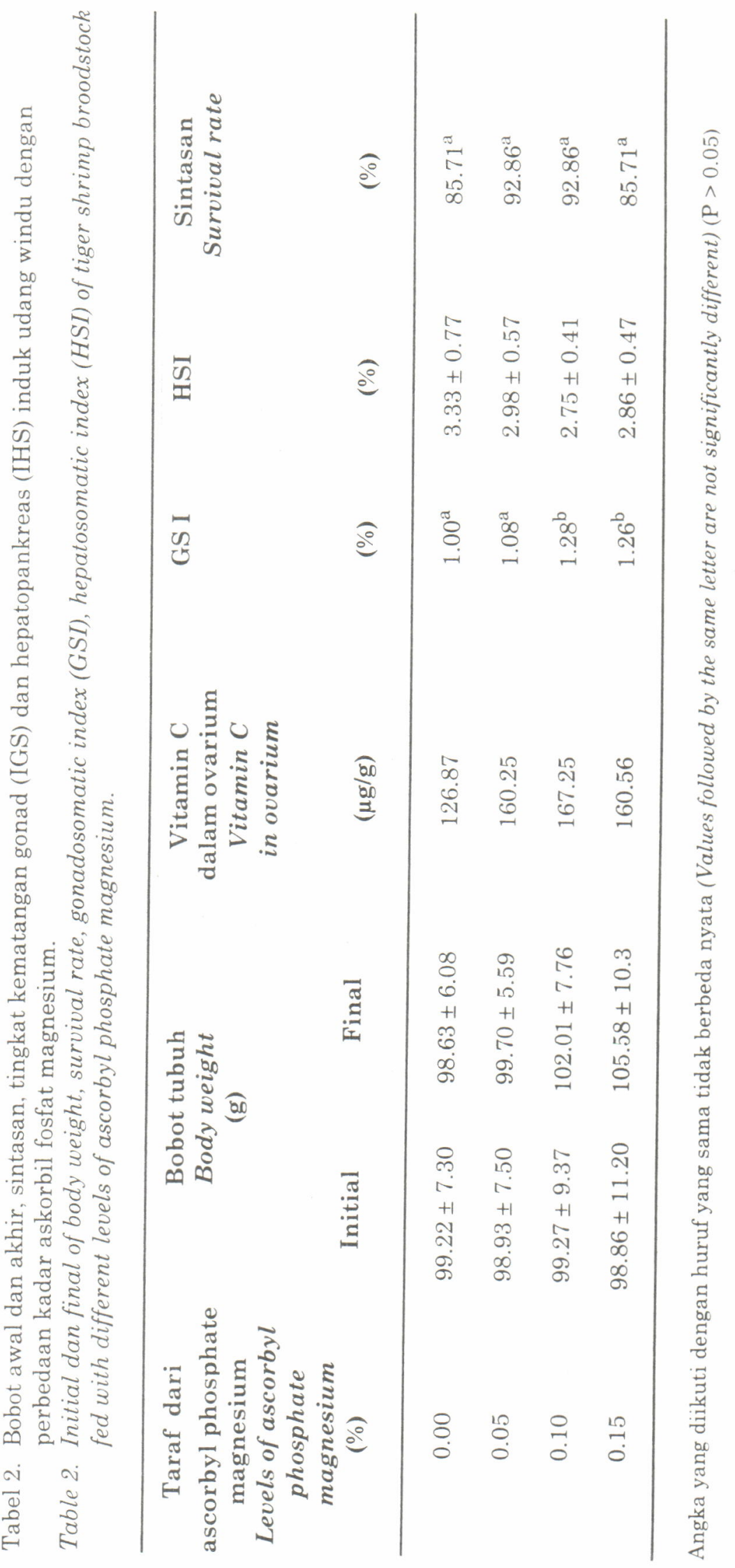


Vlaming, 1980). Hasil pengamatan terhadap IHS udang uji memperlihatkan bahwa IHS pada perlakuan kontrol jauh lebih tinggi, yaitu sekitar $3,33 \%$ dibandingkan perlakuan suplementasi askorbil fosfat magnesium yaitu berkisar 2,75. $2,98 \%$ (Tabel 2). Ini menunjukkan bahwa ada mobilisasi material dari hati ke gonad lebih tinggi pada perlakuan suplementasi askorbil fosfat magnesium. Hal ini sesuai dengan pendapat Ishibashi et al. (1994) dan Wiengfield dan Grimm (1977) yang mengemukakan bahwa rasio bobot hati terhadap tubuh (IHS) pada induk ikan akan meningkat menjelang vitelogenesis, dan kemudian rasio akan menurun karena ada mobilisasi material dari hati ke ovarium. Lebih rendahnya IHS pada suplementasi askorbil fosfat magnesium, berkaitan dengan mobilisasi material ke ovarium dan ini diikuti oleh peningkatan IGS.

Dengan demikian dari percobaan ini diketahui bahwa suplementasi askorbil fosfat magnesium sebagai sumber vitamin $\mathrm{C}$ dapat menstimulasi pematangan gonad, dan suplementasi pada dosis $0,10 \%$ sudah cukup untuk meningkatkan pematangan gonad.

Hasil pengamatan terhadap sintasan udang uji terlihat bahwa pada masa pemeliharaan tahap pertama yaitu masa pemeliharaan 36 hari tidak ditemui induk yang mati, namun setelah ablasi dan hingga hari ke 22 tercatat bahwa jumlah induk yang hidup pada kontrol dan suplementasi $0,15 \%$ mencapai $85,71 \%$ dan pada suplementasi masing-masing $0,05 \%$ dan $0,10 \%$ mencapai $92,86 \%$. Hasil analisis statistik memperlihatkan bahwa suplementasi askorbil fosfat magnesium tidak berpengaruh nyata $(P>0,05)$ terhadap sintasan udang uji. Terjadi kematian pada masa ini terutama disebabkan stres akibat ablasi. Hasil percobaan ini berbeda dengan hasil yang ditemui Alava et al. (1993) bahwa suplementasi askorbil fosfat magnesium sangat nyata mempengaruhi sintasan induk setelah ablasi, kematian tertinggi ditemui pada kontrol (tanpa suplementasi). Perbedaan hasil yang ditemui dari percobaan ini dengan penelitian oleh Alava et al. (1993) disebabkan perbedaan lama periode penelitian. Penelitian oleh Alava et al. (1993) dilakukan 120 hari, sedangkan pada percobaan ini hanya berlangsung 58 hari. Masa percobaan ini akan mempengaruhi kadar vitamin $\mathrm{C}$ pada jaringan. terutama pada perlakuan kontrol, karena udang dan ikan tidak mampu mensintesis vitamin $\mathrm{C}$ dalam tubuh sehingga ketersediaan vitamin $\mathrm{C}$ dalam jaringan akan digunakan untuk menjaga kenormalan metabolisme sel. Oleh karena itu, kadar vitamin $\mathrm{C}$ dalam ovarium akan terus menurun. Penelitian Tucker dan Halver (1983), memperlihatkan bahwa waktu paruh kandungan vitamin $\mathrm{C}$ dalam jaringan tubuh ikan salmon mencapai periode 3 bulan, dan waktu paruh akan lebih singkat jika ikan menerima suplementasi vitamin C dalam pakan. Sehingga makin lama periode ikan atau udang tidak menerima suplementasi vitamin $\mathrm{C}$ atau suplementasi vitamin $\mathrm{C}$ ransum lebih rendah dari kebutuhan, maka kadar vitamin $\mathrm{C}$ jaringan akan lebih rendah. Walaupun kandungan vitamin $\mathrm{C}$ pada hepatopankreas dalam percobaan ini tidak diamati, namun sudah dapat diduga bahwa kandungan vitamin $\mathrm{C}$ jaringan pada udang percobaan Alava et al. (1993) akan lebih rendah dibandingkan udang pada percobaan ini. Menurut Sandnes dan Waagbo (1991) jika ikan mengalami "stress" fisik terjadi peningkatan metabolisme glukosa dan kadar hormon kortisol, yaitu hormon yang berperanan dalam menjaga fungsi haemostatis sel. Horning et al. (1984) mengemukakan bahwa, vitamin $\mathrm{C}$ yang diakumulasikan pada jaringan kortek adrenal pada hewan atau ginjal anterior ikan berperanan sebagai kofaktor dalam reaksi hidroksilasi biosintesis kelompok hormon adrenokortikosteroid yang berperanan dalam mengatur metabolisme tubuh pada saat "stress", sehingga kekurangan vitamin $\mathrm{C}$ akan mengurangi kemampuan toleransi ikan terhadap gangguan "stress". Penelitian Lovell dan Lim dalam Sandnes (1991) mencatat bahwa kebutuhan vitamin C "catfish" yang dipelihara pada kepadatan yang tinggi akan meningkat dibandingkan kepadatan normal, dan hal ini disebabkan pada kondisi kepadatan yang tinggi, ikan cenderung dalam keadaan "stress".

\section{KESIMPULAN DAN SARAN}

- Suplementasi askorbil fosfat magnesium sebagai sumber vitamin $\mathrm{C}$ dapat menstimulasi pematangan gonad induk udang windu asal tambak.

- Suplementasi askorbil fosfat magnesium pada dosis $0,10 \%$ sudah cukup untuk mempercepat pematangan gonad. 


\section{DAFTAR PUSTAKA}

Alava, R.; A. Kanazawa; S. Teshima; and S. Koshio. 1993. Effect of dietary L- Ascorbyl-2-Phosphate Magnesium on gonadal maturation of Penaeus japonicus. Bull. Jap. Soc. Sci. Fish. 59(4):691-696.

Azwar, Z.I. 1997. Pengaruh askorbil fosfat magnesium sebagai sumber vitamin $\mathrm{C}$ terhadap perkembangan ovarium dan penampilan larva ikan nila (Oreochromis sp.). Disertasi. Pascasarjana IPB. 180 hal.

Delanhunte. G. and V.L. De Vlaming. 1980. Seasonal relationship of ovary weight in the gold fish, Carassius auratus (L). J. Fish. Biol., 16:5-13.

Djojosoebagio, S. 1991. Fisiologi kelenjar endokrin II. PAU. IPB. Dept. P dan K. 253 hal.

Guary, M.M.; H.J. Cocalldi; and A. Kanazawa. 1975. Variation of ascorbic acid during ovarian development and the molting cycle in Palaemon serratus (Crustacean : Decapoda). Mar. Bio., 32:341-355.

Horning, D.; B. Glathaar; and U. Mosser. 1984. General aspects of ascorbic acids function and metabolism. Proc. Ascorbic acid in Domestic Animal. The Royal Danish Agricultural Sci.:3-24 p.

Ishibashi, Y.; K. Kato; and S. Ikeda. 1994. Effect of dietary ascorbic acid supplementation on gonadal maturation in Japanese parrot fish. Suizanzoshokun. 42(2):279-285.

Laven, S.P. And P. Sorgeloos. 1991. Variation in eggs and larvae quality in various fish and crustacean. Larviculture Symp. (Belgium27-30 Ags.):221-222.
Primavera, J.H. 1985. A review of maturation in close thelicum penaeid prawn. Proc. First. Inter. Conf. Cult. Prawn/Shrimps. Iloilo City, Philippines. p. 47. 64.

Saeymour. 1981. Gonadal ascorbic acid and changes in level with ovarian development in the crussian carp (Carassius carassius L). Comp. Biochem. Physiol. 70 A:551-553.

Sandnes, K. 1984. Some aspects of ascorbic acid on reproduction in fish. Proc. Ascorbic acid in domestic animal. Royal Danish Agricultural Soc. Copenhagen:206-212.

Sandnes, K. 1991. Studies on vitamin C in fish nutrition. Dept Fisheries and Mar. Bio. Univ. of Bergen. Norway. 32 p.

Sandnes, K. and R. Waagbo. 1991. Effect of dietary vitamin $\mathrm{C}$ and physical stress on head kidney and liver ascorbic acid, serum cortisol, glucose and haematology in atlantic salmon (Salmo salar)/ Fisk. Dir. Skr. Ser. Emaring, Vol IV. No. 1: 41-49.

Tucker, R.W. and J. E. Halver. 1989. Distribution of Ascorbil-2-sulphate, half life and turn over rate of (C14) ascorbic acid in rainbow trout. J. Nutrition. 114:991-1000.

Waagbo, R.; T. Thorson; and K. Sandnes. 1989. Role of dietary ascorbic acid in vitellogenesis in Rainbouw trout. Aquaculture, 80:301-314.

Wingfield, J.G. and A.S. Grimm. 1977. Seasonal changes in plasma cortisol, testoteron, and oestradiol-17 $\beta$ in the plaice, Pleuronectes platessa L. Gen. and Comp. Endocrine, 31:1-12. 